\title{
The Impact of Emergency Remote Teaching on the Development of Listening Skills during English Classes in Secondary Schools of Ukraine
}

\author{
Iryna Simkova ${ }^{1}$, Oleksandra Bondarenko ${ }^{2}$ \\ ${ }^{1,2}$ Igor Sikorsky Kyiv Polytechnic Institute, Ukraine
}

\begin{abstract}
This paper calls into question the impact of Emergency Remote Teaching on the Development of Listening Skills during English classes in Secondary Schools of Ukraine. Attention is paid to the analysis of key notions and concepts of listening skills development in secondary schools. Thirty teachers at secondary schools took part in the research. This paper investigates resources that were used by teachers during Emergency Remote Teaching to develop the listening skills of pupils in English classes. This paper discusses the linguistic, psychological, and methodological components of listening skills development. An analysis has allowed highlighting the positive experience of web-based applications, video podcasts, and audiobooks usage, which can be implemented in future English language training in other Ukrainian secondary schools. The findings of this study support the idea that the gamification approach in combination with other activities has a positive effect on the development of listening skills during Emergency Remote Teaching at secondary schools of Ukraine.
\end{abstract}

KEYWORDS: Emergency Remote Teaching, English Language, Listening Skills, Pupils Training, Secondary School

\section{INTRODUCTION}

In March 2020 several pneumonia cases with a mysterious etiology were reported in the western part of Ukraine. World Health Organization (WHO) determined this pneumonia as a novel Coronavirus COVID-19. It has a huge influence on the educational process [1]. As far as the Ministry of Education of Ukraine [2] provides autonomy for higher and secondary schools and the general trends have moved toward "do not stop training" and continue remote teaching using diverse approaches. While disease spread globally, almost all higher and secondary schools converted the curriculums to an online environment using different digital tools and educational websites. In the history of higher and secondary schools of Ukraine, the focus has always been on converting the curriculum to an online environment rather than focusing on online pedagogy.

In this study, Emergency remote teaching (ERT) is considered as a sudden temporary shift of instructional delivery to an online delivery mode as a result of some catastrophe [3]. Unlike the online courses, which are thoughtfully planned by teachers and designed to be delivered virtually, ERT includes ultimate exploitation of the approachable remote teaching tools for delivering the educational materials that would usually be delivered physically.

In Ukraine, it is common knowledge that English is considered the language of international communication, and possessing a fluent English language becomes an integral part of our life. Thus, the school learning process is focused on practical possessing of the English language and, as a result, great attention is given to the problems of English communication comprehension.

Communication in English is primarily a social process that comprises an exchange of experience, methods of activities, skills, subskills, and performance results [4; 5]. [6] points out that communication in English is always rational and emotional interaction of individuals, within this activity the community is revealed its thoughts in such a way of life is formed. It believes as the most important condition for the formation of consciousness and self-awareness of an individual. Oral communication in English can be seen as two sides of a single phenomenon such as speaking and listening. Thus, listening can be realized as an independent type of speech activity (for example, listening to reports, films, etc.) or participate in spoken interaction as a receptive component, being the one side of speaking.

Researchers [7;8] have always differentiated the concepts of listening and hearing that are nonsynonymous. Hearing contributes to the perception in the acoustic scale, while listening presupposes hearing, which combines understanding and interpretation of the perceived information. Listening is a type of activity that plays an important role in the personal life as well as the educational and cognitive activity of pupils. It is considered as a source of information for the purpose of enriching knowledge, raising the cultural 


\section{International Journal of Current Science Research and Review}

ISSN: 2581-8341

\section{Volume 04 Issue 09 September 2021}

DOI: 10.47191/ijcsrr/V4-i9-10, Impact Factor: 5.825

level, a means of satisfying aesthetic and cultural needs, and also performs a regulatory function, since the instructions received in the process of listening determine pupils' actions.

The development of listening skills has received much attention in the past decade as an active process [9; 10] that enhances critical thinking and mental processes, the received information is perceived in the form of sound, it occurs processing and comparison with the sample stored in the long-term memory of pupils, there is recognition and understanding of thoughts.

Considering that at the secondary school during English class most of the school time pupils listen to teachers and classmates, it becomes obvious that the ability to hear and comprehend what is perceived as the most important necessary skill, lack of it influences both learning at secondary school and pupils' life. During the pandemic period, major challenges related to rapid digitalization of curriculum and alternate online delivery modes used during the development of English language skills (listening, reading, writing, and speaking) occurred.

Thus, this paper investigates the impact of Emergency remote teaching on the development of listening skills during English classes in secondary schools of Ukraine. To reach the aim of the study, we will broaden the current knowledge about the development of listening skills during English classes, examine the ways of teaching English in secondary schools of Ukraine; implement the activities aimed at the development of listening skills during English classes in secondary schools within Emergency remote teaching; interview teachers who participated in the experimental study from two Ukrainian secondary schools (located in Kyiv); validate finding regarding listening skills development during English classes.

\section{METHODS}

General Background of Research

To achieve the goals of the study, a complex of interrelated methods of scientific research has been used. The main theoretical methods used in the study are the generalization of pedagogical and psychological literature to consider the theoretical backgrounds of an Emergency remote teaching in Ukraine; the comparative analysis to stipulate the role of ERT in the development of listening skills during English classes. The empirical methods used in the study are the observation of the educational process in five secondary schools of Ukraine located in Kyiv (School № 52, 54, 22, 76, and School № 173); the quantitative and qualitative analysis of experimental data to show the impact and a role of ERT in the development of listening skills during English classes.

To demonstrate the impact of the ERT on the development of listening skills during English classes, the study was carried out among secondary school teachers. A total of 30 teachers were recruited for semi-structured interviews. Interviews were conducted informally. We chose a small sample size due to the fact that usually there are about 5-6 teachers of English in secondary schools of Ukraine that located in Kyiv. The schools were chosen randomly.

The teachers who participated in the survey have to answer four questions:

1. Was it hard for you to develop pupils' listening skills within the Emergency remote teaching?

2. Was it difficult for you to find the applicable digital tools to develop pupils listening skills within the Emergency remote teaching?

3. What kinds of activities you proposed to your pupils to develop their listening skills within the Emergency remote teaching brought the most promising results?

4. Does the use of digital tools during English classes within the Emergency remote teaching help pupils feel more confident during their communication?

The teachers may answer "Yes" or "No" for questions number 1, 2, and 4 and they can also make their comments. Question 3 needs much more specific answers.

\section{RESULTS}

The quantitative and qualitative analysis of experimental data indicates that the sample was 30 were recruited with a response rate of $99.5 \%$. A majority $(70 \%)$ were above 50 y.o. 


\section{International Journal of Current Science Research and Review}

ISSN: 2581-8341

Volume 04 Issue 09 September 2021

DOI: 10.47191/ijesrr/V4-i9-10, Impact Factor: 5.825

IJCSRR@ 2021

www.ijcsrr.org

Table 1: Age distribution of the teachers

\begin{tabular}{l|l|l}
\hline Age category & Frequency $(\mathbf{N})$ & Percentage $(\%)$ \\
\hline From 21 to 24 & 3 & 10 \\
\hline From 25 to 35 & 6 & 20 \\
\hline From 36 to 46 & 12 & 40 \\
\hline Below 46 & 9 & 30 \\
\hline Total & 30 teachers & $100 \%$ \\
\hline
\end{tabular}

Considering the data provided in Table. 1. we can see that respondents are represented by different ages.

Half of the respondents ( 15 teachers) mostly aged between 36 and below 46 agreed that it was hard for them to develop pupils' listening skills within the Emergency remote teaching.

At the same time, fifty per cent of surveyed teachers aged between 36 and below 46 reported that they strongly disagree with the statement that it was hard. The teacher said:

"Emergency remote teaching was an unexpected solution for me, I have no experience in using digital tools, I feel it becomes more complicated".

Sixty per cent of respondents aged 25 to 46 said that it was difficult for them to find the applicable digital tools to develop pupils' listening skills.

One of the teachers said:

"To find applicable and approachable tools I have been spending evenings surfing the Internet".

At the same time, almost $90 \%$ of teachers mentioned that participation in English teaches communities and professional associations, visiting professional training and webinars provided by Pearson Education, Dinternal Education, and British Council Ukraine helped them to decide.

One of the respondents said:

"Participating in the webinars and communication with my colleagues from different schools provided me with a lot of information and ideas".

The majority of respondents (about 95\%) believe that properly selected digital tools for listening skills development provide their pupils with a confident feeling in listening and speaking during communication.

The ideas expressed by teachers are well consistent with Sejdiu (2017) [11] that suggests that the particular multimedia tools rise the effectiveness in producing language outcomes for students.

Among resources teachers proposed to their pupils to develop their listening skills within the Emergency remote teaching were mentioned video podcasts, audiobooks, web-based applications (Kahoot, Flipgrid, Vocaroo, WeVideo).

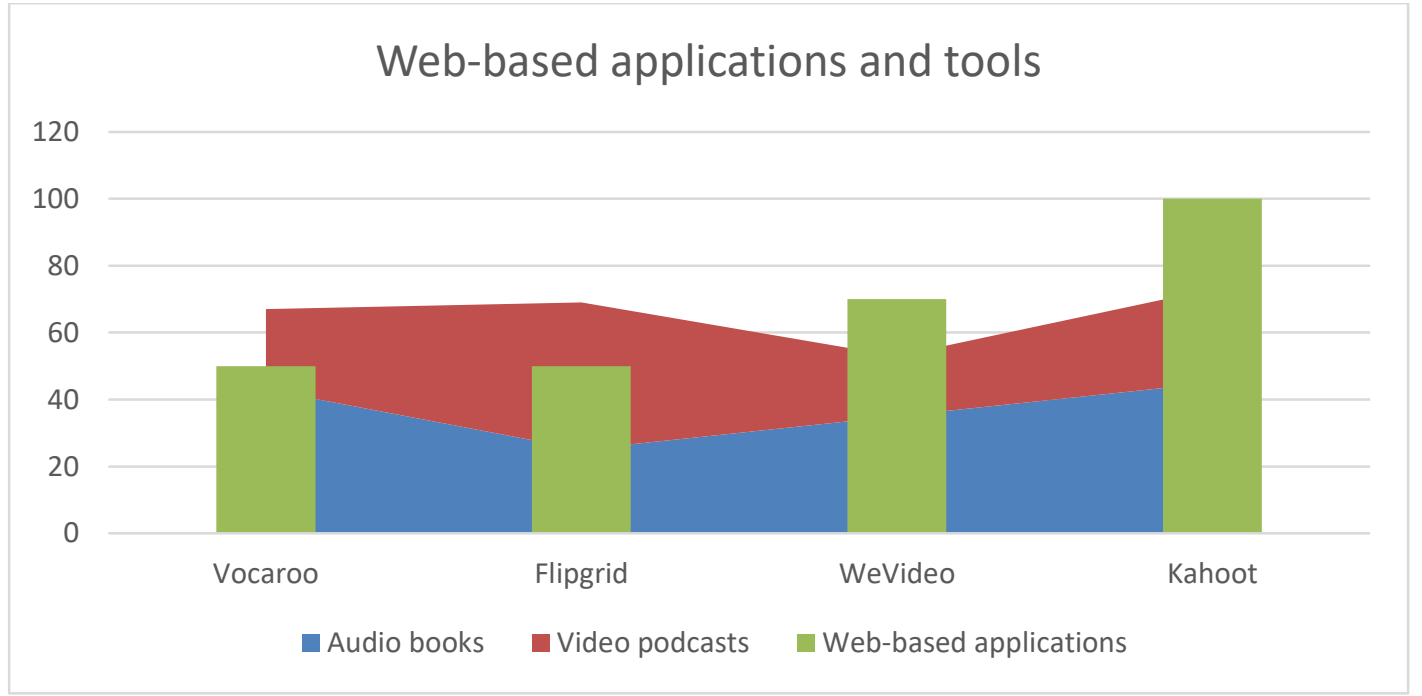

Figure 1: Resources and tools used for listening skills development during English classes 


\title{
International Journal of Current Science Research and Review
}

\author{
ISSN: 2581-8341
}

\section{Volume 04 Issue 09 September 2021}

DOI: 10.47191/ijcsrr/V4-i9-10, Impact Factor: 5.825

An analysis of recent findings regarding resources teachers proposed to their pupils to develop their listening skills within the Emergency remote teaching has led to the suggestion that web-based applications are used much more actively than audiobooks and video podcasts. One of the most popular web-based applications is Kahoot, it is used by $100 \%$ of teachers. The majority of respondents $(70 \%)$ use the application WeVideo. Fifty per cent of those interviewed indicated that they use Flipgrid and Vocaroo.

Some respondents mentioned that the reason they use Kahoot more than other web-based applications is based on the pupils' preferences. These results offered by requested teachers is vital evidence for the fact that one of the most favorite pupils' application is Kahoot and WeVideo, whereas Flipgrid and Vocaroo look less attractive for pupils. In our opinion, it can be explained by the aims they are accomplished. For instance, with the help of WeVideo teachers can use video creatively to engage pupils in learning, it also allows teachers and pupils to make their videos or podcasts. Flipgrid in most cases lets pupils use 15-second to 5-minute videos to respond to prompts or provide feedback to watched podcasts or lusted audiobooks. Vocaroo helps to embed the recording into slideshows, presentations, or websites; pupils can create audio recordings without the need for software.

This finding confirms the usefulness of web-based applications, audio books, and video podcasts as a powerful tool for the development of listening skills during English classes in secondary schools of Ukraine during the ERT period.

\section{DISCUSSION}

More recent evidence [12] shows that pupils spend $70 \%$ of their time at school in oral communication, where the use of listening skills is $45 \%$. Experts highlight that perception of information by listening in the English class takes a substantial part from 40 to $60 \%$. It is considered that listening skills are gained by the individual from his/her birth, and therefore it is a basic skill in possessing speaking, reading, and writing. Nevertheless, by school age, the child does not always possess good listening skills. The investigations into listening skills development for pupils found that pupils do not perceive up to $75 \%$ of oral information. Listening to educational information presents a particular difficulty for pupils.

In recent years there has been growing interest in the problem of listening skills development. Much work on the potential of listening skills development in secondary schools has been carried out [13; 14], however, there are still some critical issues about practical the use of certain approaches, teaching methods, and tools to develop listening skills during Emergency remote teaching.

A review of the literature on this topic $[15 ; 16]$ found that listening as any type of speech activity has its peculiar horizontal structure. Bredihina [17] and Zimnyaya [18] distinguish three phases in listening: motivational, analytical, and productive. The motivational phase helps to set goals in the communicative task. Before starting a task aimed at the development of listening skills, pupils must be informed of what they will listen to and what exactly they should hear. The motive is created by an interesting exposition, conversation about the author, the topic of the conversation. In real-life communication, the source of the motive for perception and understanding is the topic of communication and the participant of communication himself/herself (his/her manner of communication, ability to attract the attention of the listener, etc.).

The analytical phase is the main part of the listening. It includes the perception and processing of the information that comes through the audio canal. By using the above mechanisms (audio memory, prediction, identification, etc.), an inference occurs and understanding comes in the end.

The target listening result, preliminary listening, the executive stage in listening merges with the analytical phase. In real-life communication, the result of listening, i.e. understanding remains hidden. During the development of the listening skills, it must be observed in order to monitor the development of listening skills. As a result, experts say understanding is a vital factor in the monitoring of pupils' listening skills development. Web-based applications assist teachers when it is necessary to receive feedback from pupils, it may be a verbal or non-verbal response from the pupils. It helps the teacher to understand if pupils succeeded or failed to solve the communicative tasks.

The secondary school curriculum stipulates that the main goal of listening skills development as a type of speech activity is the development of the ability to understand not only educational but also real-life texts. Pupils must understand basic information, select information relevant to set questions and be able to find necessary details.

A growing body of literature has studied the linguistic, psychological, and methodological components of listening skills development. The linguistic component of listening skills development [19] focuses on the language material and includes language units (phonemes, morphemes, collocations, phraseological combinations, micro-and macro-texts). It has now been suggested that the linguistic component is connected with the development of language units, which occurs in real-life communication. Units of 


\title{
International Journal of Current Science Research and Review
}

\author{
ISSN: 2581-8341
}

\section{Volume 04 Issue 09 September 2021}

DOI: 10.47191/ijcsrr/V4-i9-10, Impact Factor: 5.825

communication are situationally conditioned statements of various lengths (speech patterns, micro-, and macro text). Hence, the linguistic component of listening consists of understanding units of language and understanding of units of speech (i.e., even if there is an aim to understand a word, it is done (completed) in speech units).

Rixon [20] underlines that the psychological component of the listening skills development ensures the functioning of listening mechanisms, as well as actions with specific language and speech material, which with the help of training turns in skills and abilities. The psychological component of the listening skills development includes 1) separation of the main information from the secondary (defining the subject of the message); 2) division of the text into semantic parts; 3) establishment of logical connections between utterances; 4) highlighting of the main idea; 5) perception of the message with a certain pace, a certain duration, until the end without gaps. The psychological component brings perception to understanding in the English language at the level where occurs the development of pronunciation, lexical, and grammatical skills.

The methodological component deals with training and compensatory skills development, it comprises teaching techniques on the perception and understanding of English speech. This component includes the ability to keep records during listening, use visual supports, avoiding difficulties, use information that precedes listening (pictures, plan, keywords), as well as rely on pupils' life experience, knowledge of the subject of the communication. Listening skills are complex and interrelated. Their development is based on the synchronous work of many mechanisms and on the structure of listening as a type of speech activity. Richards [21], an authority on the methodological component of listening skills development, notes that in the act of communication verbal means (speech) occupy $35 \%$, the rest of the means are non-verbal.

Some studies have proposed to form in pupils the ability to use a certain listening algorithm (when extracting information from audio text): 1) highlight the title of the text and identify the person who is talking; 2) indicate characters of communication and events; 3 ) express their own attitude to what you listened to.

In the development of listening skills, usage of video podcasts and audiobooks is necessary since during communication in class pupils get used to the teacher's pronunciation as well as classmates who are not native speakers. Thus, the use of video podcasts and audiobooks creates much more opportunities for pupils to understand the speech of a wider number of people. It also influences pupils' desire to communicate in the English language and creates an important stimulus to increase motivation to learn the English language.

In offline classes to improve the effectiveness of listening skills development teachers may use different teaching aids, visual or verbal support. Among visual aids are maps, pictures, photographs, diagrams, plans, and other graphic materials. Verbal supports can be presented in the form of keywords, content plan, headlines, a variety of questionnaires that allow pupils to split the text in accordance with the proposed method. During ERT teachers experience difficulty with providing visual or verbal support. Thuswise it is important to teach pupils to control the multiple presentations of the same audio texts and find landmarks in the audio text by themselves (identify intonationally highlighted words, headings, and subheadings, words with logical stress, rhetorical questions, repetitions, etc.). Pupils must understand that presentation of audio text two or three times is advisable when tasks relate to retelling or discussion of the text. Re-listening should be preceded by the formulation of new practical tasks that require from pupils a deeper understanding.

A growing body of literature [22; 23] has proposed to break down the work with the audio text into the following stages: pretext, text, and post-text. During class training these stages can be represented as follows:

1. Briefing and pre-assignment.

2. Perception of the audio text.

3. Control of comprehension of audio text.

Emergency Remote Teaching requires the use of web-based applications that may be associated by many pupils as virtual games just for playing. For this reason, teachers must remember web-based applications are not an element of entertainment but are aimed at the performance of some tasks and gain particular results. Newly qualified teachers are obliged to remember the concept and meaning of "gamification" [24]. It includes a fairly extensive group of methods and techniques for organizing the pedagogical process in the form of a variety of educational games. They have a clearly defined learning goal and corresponding pedagogical results that are followed by educational and cognitive characteristics.

The Gamification approach is built as a holistic model that covers a dedicated part of the learning process and is united by a common content plot as well as a character [25]. It includes sequentially games and exercises that form the ability to find bright, 


\section{International Journal of Current Science Research and Review}

ISSN: 2581-8341

\section{Volume 04 Issue 09 September 2021}

DOI: 10.47191/ijcsrr/V4-i9-10, Impact Factor: 5.825

specific features of objects, compare, contrast them; groups of games for generalizing objects on certain grounds; groups of games during which schoolchildren develop the ability to distinguish real from unreal; groups of games that teach self-control, develop a quick reaction to a word, phonemic hearing, ingenuity, etc. In this case, the game plot develops parallel to the main goal of learning, enters this process, helps intensify learning, possesses some educational elements, but in no way replaces it, and does not rule. As a result, every teacher can compile the gaming technologies based on different games and elements to suit the target needs of pupils.

The advantage of gamification for language skills development can increase interest in learning in pupils, positive emotions, help to focus on the learning task, which changed from the external goal to a personal goal. It makes it possible to decide learning tasks in a relaxed atmosphere of freedom, raise the interest and activity of pupils, built a joint spirit of friendship. In a game situation, the processes of perception, understanding, and assimilation take place in the mind of the pupil more accurately and quickly [26].

Gamification fulfills two main functions in listening skills development. The first function is to improve and consolidate listening skills knowledge. At the same time, pupils do not reproduce knowledge in the form in which they have been assimilated, he/she processes and transforms them, learns to use them in the right situation, and regardless of the education or real-life situation. The second function is that pupils learn at the same time knowledge and skills of different content. Our work has led us to conclude that usage of web-based applications, video podcasts, and audiobooks in combination with the gamification approach has a positive effect on the development of listening skills during Emergency Remote Teaching at secondary schools of Ukraine.

\section{CONCLUSIONS}

Our study provides the basis to explore the impact of Emergency Remote Teaching on the development of listening skills during English classes in secondary schools of Ukraine. Our investigations into this area are in progress and seem likely to confirm our hypothesis that during ERT usage of video podcasts, audiobooks, and web-based applications has a positive impact on listening skills development in secondary schools of Ukraine.

We believe that our research will serve as a base for future studies on the exploring of other activities that enhance the listening skills development in other secondary schools of Ukraine during ERT. We hope it proves the necessity to develop other technologies in other secondary schools of Ukraine, which will allow teachers to enhance such activities as reading, writing, and speaking in the classroom and during Emergency Remote Teaching. Our results are encouraging and should be validated by a larger sample size. We are also open to suggestions and ideas that can help secondary schools of Ukraine improve English language teaching to satisfy teachers' needs and pupils' needs in the learning process.

\section{REFERENCES}

1. Sohrabi, C., et al. World Health Organization declares global emergency: a review of the 2019 novel Coronavirus (COVID19) Int J Surg. 2020;76(5):71-76. doi: 10.1016/j.ijsu.2020.02.034.

2. Zakon Ukrayiny` Pro vy`shhu osvitu [Law of Ukraine on higher education] (2014). № 1556-VII. Retrieved from http://zakon3.rada.gov.ua/laws/show/1556-18/conv/page. (in Ukrainian).

3. Mohmmed, A.O., Khidhir, B.A., Nazeer, A., \& Vijayan, V.J. Emergency remote teaching during Coronavirus pandemic: the current trend and future directive at Middle East College Oman. Innov. Infrastruct. Solut. 2020; 5(3):72. doi: 10.1007/s41062-020-00326-7. Epub 2020 Jul 1. PMCID: PMC7327487.

4. Akinnubi, O. P., Gbadeyan, C. O., Fashiku, C. O. and Kayode, D. J. Effective Communication: A Tool for Improvement of Secondary School Management. Journal of Education and Practice. Vol 3, No 7, 2012. www.iiste.org

5. Simkova, I., Morska L. (2020). Communication of Ukrainian Schoolchildren in Social Networks: Linguistic and Pedagogical Aspects. Pedagogical Contexts 2020, No. 1(14), pp. 67-81, ISSN 2300-6471 https://doi.org/10.19265/kp.2020.1.14.244

6. Rohmah, I. I.T. Classroom Interaction in English Language Class for Students of Economics Education. Arab World English Journal, 8 (2). 2017. DOI: https://dx.doi.org/10.24093/awej/vol8no2.14

7. Perry, C., Jr., \& Marsh, H. W. Listening to self-talk, hearing self-concept. In M. B. Andersen (Ed.), Doing sport psychology, pp. 61-76. 2000. Human Kinetics.

8. Beck, D.L., Flexer. C. Listening is where hearing meets brain...in children and adults. Hearing Review. 2011; 18(2):30-35.

9. Lemke, Ul. Besser, J. Cognitive Load and Listening Effort: Concepts and Age-Related Considerations, Ear and Hearing: July/August 2016 - Volume 37 - Issue - p 77S-84S doi: 10.1097/AUD.0000000000000304 


\section{International Journal of Current Science Research and Review}

ISSN: 2581-8341

Volume 04 Issue 09 September 2021

DOI: 10.47191/ijesrr/V4-i9-10, Impact Factor: 5.825

IJCSRR@ 2021

www.ijjcsrr.org

10. Gulec, S. and Durmus, N. A Study Aiming to Develop Listening Skills of Elementary second Grade Students. Procedia Social and Behavioral Sciences. Vol. 191. 2015, pp. 103-109, https://doi.org/10.1016/j.sbspro.2015.04.487.

11. Sejdiu, S. Are Listening Skills Best Enhanced Through the Use of Multimedia Technology. Digital Education Review. N. 32, December 2017. http://greav.ub.edu/der/

12. Fisher, D. \& Frey, N. Speaking and Listening in Content Area Learning. The Reading Teacher, 68(1), 2014. 64-69 doi: $10.1002 / \operatorname{trtr} .1296$

13. Garcia, Rosalinda C. The Role of Information and Communication Technology in Secondary Schools. Doctoral dissertation, Texas A \& M University. 2018. Available electronically from https : / /hdl .handle .net /1969 .1 /173709.

14. Akhtar, Sh. Role of ICT in the Enhancement of English Language Skills among the Learners. Journal of Technology for ELT. Vol. 7 N. 2. 2017. Available at https://sites.google.com/site/journaloftechnologyforelt/archive/volume-6-no/2-role-ofict-in-the-enhancement-of-english-language-skills-among-the-learners

15. Dell'Antonio, Andrew, ed. Beyond Structural Listening?: Postmodern Modes of Hearing. University of California Press, 2004. Accessed September 12, 2021. http://www.jstor.org/stable/10.1525/j.ctt1pq0kr.

16. Houston, H. The Three Stages of a Listening Activity. EFL Magazine (The Magazine for English Language Teachers). 2017. Available: https://eflmagazine.com/the-three-stages-of-a-listening-activity/

17. Bredihina, I. The methodology of teaching foreign languages. Ekaterinburg, 2018. [in Russin]

18. Zimnyaya, I. Linguphyhology of speech. Voronezh. Modek .2001 [in Russian]

19. Rost, M. Teaching and researching listening. Second edition. Harlow: Longman, 2011.

20. Rixon, S. Developing listening skills. London: Macmillan, 1986.

21. Richards, J. C. Teaching listening and speaking: From theory to practice. Cambridge University Press. 2008.

22. Naidionova, A. and Ponomarenko, O. Use of Podcasting Technology to Develop Students' Listening Skills. Information Technologies and Learning Tools. Vol. 63, 2018. doi 10.33407/itlt.v63i1.1962

23. Metruk, R. (2019). Using English Movies and TV Programs for Developing Listening Skills of EFL Learners. Information Technologies and Learning Tools, 70(2), 227-236. https://doi.org/10.33407/itlt.v70i2.2488

24. Swain, R. Essential skills for secondary school teachers. PROSPECTS. 2020. Available at https://www.prospects.ac.uk/jobsand-work-experience/job-sectors/teacher-training-and-education/essential-skills-for-secondary-school-teachers

25. Ishaq, K., Mat Zin, N. A., Rosdi, F., Jehanghir, M., Ishaq, S., \& Abid, A. Mobile-assisted and gamification-based language learning: a systematic literature review. Peer J. Computer science, 7, 2021. e496. https://doi.org/10.7717/peerj-cs.496

26. Rahmawati, N. Desi. Designing a set of supplementary listening materials using gamification in the intermediate listening class. Pendidikan Bahasa Inggris, JPBS, FKIP, Yogyakarta: Universitas Sanata Dharma. 2016.

Cite this Article: Iryna Simkova, Oleksandra Bondarenko (2021). The Impact of Emergency Remote Teaching on the Development of Listening Skills during English Classes in Secondary Schools of Ukraine. International Journal of Current Science Research and Review, 4(9), 1146-1152 